DEPARTAMENTO DE LETRAS

Curso de Formação de Intérpretes de Conferência

A interpretação de tribunal nas Varas Criminais da Subseção da Capital da Seção Judiciária do Estado do Rio de Janeiro

Andrei Winograd

Profa ${ }^{-}$Orientadora: Silvia Beatriz Alexandra Becher Costa 
Andrei Winograd

\section{A interpretação de tribunal nas Varas Criminais da Subseção da Capital da Seção Judiciária do Estado do Rio de Janeiro}

Monografia apresentada ao Programa de Pós-Graduação em Letras da PUC-Rio como requisito parcial para obtenção do diploma do curso deEspecialização Formação de Intérpretes de Conferência. Aprovada pelaComissão Organizadora abaixo assinada.

Professora Orientadora:

Prof ${ }^{\text {a }}$ Sílvia Beatriz Alexandra Becher Costa 
Agradecimentos

Aos professores, alguns dos quais são agora colegas de profissão, por me terem proporcionado um curso tão bom e divertido.

À Prof ${ }^{a}$. Sílvia Becher pela orientação dada neste trabalho.

Aos colegas de curso, todos os quais são agora amigos, por me terem proporcionado intervalos para o cafezinho tão bons e divertidos.

Aos juízes entrevistados, por terem me dado o seu tempo e a sua atenção.

Ao Procurador Regional da República e amigo Rogério José Bento Soares do Nascimento, pela valiosíssima ajuda. 


\section{Resumo}

O presente trabalho tem por objetivo verificar (1) a existência de normas, além dos dispositivos legais, que regulem a atuação do intérprete em audiência na Justiça Federal, (2) as linhas gerais dessa atuação e (3) como os juízes avaliam o trabalho dos intérpretes.

Para tanto, realizaram-se entrevistas com os juízes titulares de todas as dez varas criminais da Subseção da Capital da Seção Judiciária do Estado do Rio de Janeiro.

Os resultados das entrevistas indica que, nos limites da lei, cada juiz conduz a atuação do intérprete da forma que lhe parece mais conveniente e que a vasta maioria dos juízes está satisfeita com o desempenho dos intérpretes, não obstante o uso frequente de intérpretes não-profissionais.

Palavras-chave: interpretação de tribunal, tradutor juramentado, tradutor público, intérprete ad-hoc, Justiça Federal. 


\section{Abstract}

The purpose of this paper is to verify (1) if there are rules other than statutory provisions regulating interpreting in hearings held in the Federal Court System, (2) how interpreting generally occurs and (3) how judges assess the work of court interpreters.

To answer these questions, all head judges of the ten criminal courts in the Subdistrict of the State Capital within the Federal Judicial District of the State of Rio de Janeiro were interviewed.

Results from the interviews indicate that, within the boundaries of the law, each judge guides the work of the interpreters as $s /$ he thinks fit and that the vast majority of judges is satisfied with the performance of interpreters regardless of the frequent use of non-professional interpreters.

Keywords: court interpreting, sworn translator, public translator, adhocinterpreter, Federal Court System 


\section{Sumário}

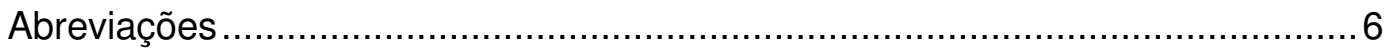

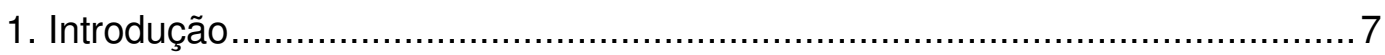

2. A tradução e a interpretação ................................................................. 9

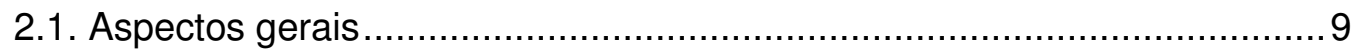

2.1.1. Diferenças entre a tradução e a interpretação ...................................... 9

2.1.2. Modalidades de interpretação ........................................................ 11

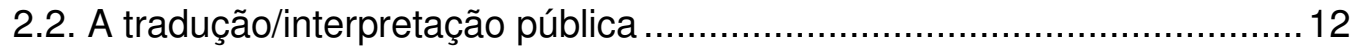

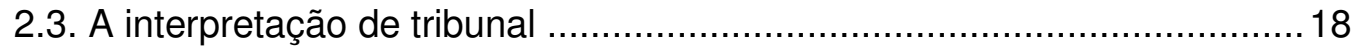

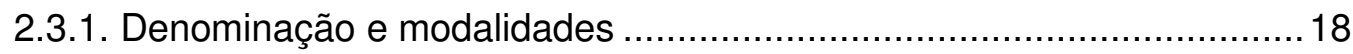

2.3.2. Regulamentação e orientações .....................................................20

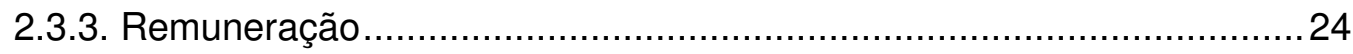

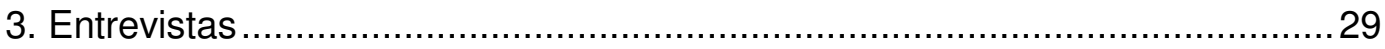

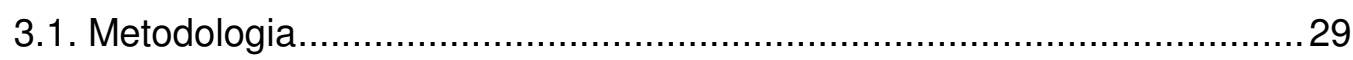

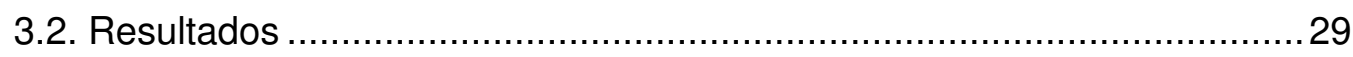

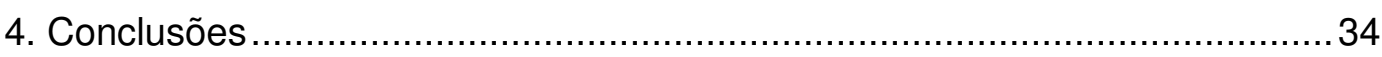

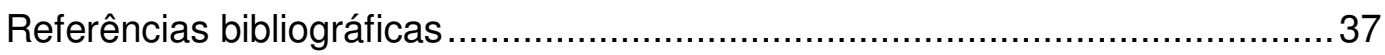

Anexo - Roteiro de Entrevista ............................................................ 41

\section{Tabelas, Gráficos e Figuras}

Tabela 1 - Avaliação da prova oral do concurso de 2009 para TPIC da JUCERJA

Tabela 2 - TPIC no Estado do Rio de Janeiro ............................................. 17

Tabela 3 - № de idiomas por TPIC.............................................................. 17

Gráfico 1 - TPIC matriculados a cada ano............................................... 18

Gráfico 2 - Remuneração do intérprete (SINTRA x JUCERJA x Justiça Federal)

Gráfico 3 - Avaliação geral da atuação dos intérpretes ................................... 31

Figura 1 - A interpretação no contexto do Direito ........................................ 19 


\section{Abreviações}

\begin{tabular}{|l|l|}
\hline ATP-Rio & $\begin{array}{l}\text { Associação Profissional de Tradutores Públicos e Intérpretes } \\
\text { Comerciais, Juramentados, do Estado do Rio de Janeiro }\end{array}$ \\
\hline CBO & Classificação Brasileira de Ocupações \\
\hline CC & Código Civil \\
\hline CJF & Conselho da Justiça Federal \\
\hline CLT & Consolidação das Leis do Trabalho \\
\hline CNJ & Conselho Nacional de Justiça \\
\hline CP & Código Penal \\
\hline CPC & Código de Processo Civil \\
\hline CPP & Código de Processo Penal \\
\hline DNRC & Departamento Nacional de Registro do Comércio \\
\hline DREI & Departamento de Registro Empresarial e Integração \\
\hline GAJ & Gratificação Judiciária and \\
\hline JUCERJA & Junta Comercial do Estado do Rio de Janeiro \\
\hline MP & MinistérioPúblico \\
\hline NAJIT & $\begin{array}{l}\text { National Association of Judiciary } \\
\text { Translators[Assoc. Nac. dos Intérpretes e TradutoresJudiciários } \\
\text { dos EUA] }\end{array}$ \\
\hline OAB & Ordem dos Advogados do Brasil \\
\hline SINTRA & Sindicato Nacional dos Tradutores \\
\hline SJERJ & Tradutor Público e Intérprete Comercial \\
\hline TRF-2 & Tribunal Regional Federal da 2ª Região \\
\hline
\end{tabular}




\section{Introdução}

Atkinson (2006) observa que o primeiro trabalho acadêmico sobre interpretação de que se tem notícia no Ocidente foi publicado em 1931 pelo psicólogo espanhol Jesús Sanz e que ela, Atkinson, tinha conhecimento de um mero punhado de teses e dissertações sobre o tema no Brasil. Diz Passos (2009) que "[n]o Brasil, estudos acadêmicos sobre interpretação forense ${ }^{1}$ são praticamente inexistentes".

Em cada um dos últimos anos, o Brasil recebeu mais de cinco milhões de turistas do exterior (2010-12) e concedeu mais de 60.000 vistos de trabalho a estrangeiros (2011-13). Em 2012 havia quase 3.300 estrangeiros nas penitenciárias brasileiras e o país recebeu mais de 2.000 pedidos de refúgio. Nem todos esses números apresentam tendência de alta. Se os pedidos de asilo mais do que triplicaram entre 2010 e 2012, a população prisional estrangeira declinou $3 \%$ no mesmo período. Se a quantidade de turistas vindos do exterior cresceu 19\% entre 2009 e 2012, apenas nesse ano se superou o recorde de 2005 e o número de vistos de trabalho concedidos caiu 10\% entre 2011 e $2013^{2}$.

Independentemente das tendências, os números absolutos são expressivos e cada turista, trabalhador, preso ou refugiado estrangeiro representa um possível usuário da Justiça brasileira, seja estadual ou federal.A interpretação de tribunal é, pois, um campo de estudos pouco explorado e que merece atenção.

Meu interesse no assunto vem da minha experiênciapessoal: sou "tradutor juramentado" e tive a oportunidade de trabalhar como intérprete numa audiência judicial ocorrida em 2012. Na ocasião, questionei-me sobre o porquê de o juiz ter conduzido minha atuação de determinada forma e agora, ao concluir o Curso de Formação de Intérpretes de Conferência da PUC-Rio, resolvi voltar à questão que me intrigou.

\footnotetext{
${ }^{1}$ Vide discussão sobre nomenclatura na Seção 2.3.1 do presente trabalho.

2 Origem dos dados (todos consultados em 11/05/2014):

Turistas: <http://www.dadosefatos.turismo.gov.br/dadosefatos/estatisticas_indicadores/ estatisticas_basicas_turismo/>

Vistos de trabalho: <http://portal.mte.gov.br/trab_estrang/estatisticas.htm>

População prisional: <http://portal.mj.gov.br/main.asp?View=\%7BD574E9CE-3C7D437A-A5B6-22166AD2E896\%7D\&Team =\&params=itemID=\%7BD82B764A-E854-4DC2A018-450D0D1009C7\%7D;\&UIPartUID=\%7B2868BA3C-1C72-4347-BE11-

A26F70F4CB26\%7D>

Refugiados: <http://www.acnur.org/t3/fileadmin/scripts/doc.php?file=t3/fileadmin/ Documentos/portugues/Estatisticas/Refugio_no_Brasil_-_Uma_analise_estatistica_20102012>
} 
O presente trabalho, que se limita à interpretação entre o português e idiomas estrangeiros, ignorando a língua de sinais, tem por objetivo verificar (1) a existência de normas que regulem a atuação do intérprete em audiência, (2) as linhas gerais dessa atuação e (3) como os juízes avaliam o trabalho dos intérpretes.

Trata-se, portanto, de um trabalho exploratório e não prescritivo. Não se faz nenhum juízo de valor sobre a condução dada pelos juízes aos intérpretes e tampouco se oferecem quaisquer recomendações.

O trabalho se divide em quatro capítulos, sendo esta introdução o primeiro. O capítulo 2 tece considerações genéricas sobre a interpretação e a tradução e acerca da tradução pública em geral e da interpretação de tribunal em particular. Dada a natureza do tema, a discussão da legislação em certa profundidade é inevitável. O capítulo 3 relata os resultados das entrevistas conduzidas com juízes das dez varas criminais federais da cidade do Rio de Janeiro e o capítulo 4 apresenta as conclusões.

Não obstante três dos entrevistados serem mulheres, refiro-me a todos os juízes sempre no masculino, não apenas porque esse gênero prevalece no plural, mas também para preservar o sigilo acerca da identidade da pessoa que fez este ou aquele comentário.

A referência a "réu" é sempre no masculino por razão de praticidade, sendo óbvio que a pessoa em questão pode perfeitamente ser mulher. 


\section{A tradução e a interpretação}

\subsection{Aspectos gerais}

\subsubsection{Diferenças entre a tradução e a interpretação}

É comum a confusão entre "tradução" e "interpretação", até a legislação o faz, como se verá na Seção 2.2. Tradutores e intérpretes têm em comum o profundo conhecimento dos idiomas envolvidos, mas há uma diferença essencial entre eles: os primeiros lidam com textos escritos e os segundos, com a linguagem falada (TAYLOR-BOULADON, 2011).Na prática, essa distinção se materializa nas diferenças entre os respectivos processos de atuação.

O tradutor dispõe de um longo tempo para traduzir ${ }^{3}$ o texto original, o que Ihe permite consultar várias fontes e voltar constantemente à sua tradução, burilando-a até que esteja satisfatória.

O intérprete trabalha em prazo curtíssimo, especialmente na modalidade simultânea (discutida mais abaixo), não podendo se dar ao luxo de gastar tempo testando diferentes soluções e raramente tendo a oportunidade de se corrigir.

"Longo" e "curto"naturalmente são categorias relativas. Um tempo longo em determinada circunstância será curto em outra. No caso em tela, o que define essas categorias são suas diferentes ordens de grandeza. Um tradutor que tenha de entregar determinado trabalho numa questão de horas considerará o prazo apertado, mas o intérprete que disponha de um minuto para dar a sua interpretação se achará um bem-aventurado.Isso tem importante implicação nos respectivos processos de trabalho.

O tradutor não apenas pode retornar aos trechos já traduzidos, ele também pode compartimentalizar seu trabalho. Ao se deparar com uma palavra ou expressão particularmente difícil, o tradutor pode nela se concentrar, suspendendo o andamento do trabalho (sem, é claro, impactaro prazo de entrega). Ele tem a liberdade de administrar o seu tempo, podendo dedicar parcelas desproporcionalmentegrandes ou pequenas a certas partes do texto.

O intérprete não pode agir dessa forma. Na modalidade simultânea, o tempo de resposta se conta em segundos ou frações. Na modalidade consecutiva, o intérprete espera alguns minutos para iniciar a interpretação, mas

\footnotetext{
${ }^{3} \mathrm{O}$ jargão diferencia a tradução (do idioma estrangeiro para o vernáculo) da versão (do vernáculo para o idioma estrangeiro). Aqui utilizo os termos "tradução" e "traduzir" indistintamente.
} 
não pode dedicar esse intervalo a meditar sobre a melhor forma de traduzir esta ou aquela palavra porque o orador continua a falar. $O$ intérprete necessita manter total concentração no orador e nas notas que por ventura tome.

Numa alegoria simples, é como se a capacidade de processamento de um tradutor ou intérprete fosse uma caixa d'água com um cano de entrada e outro de saída. O fluxo de entrada não pode superar o de saída, sob pena de a caixa d'água encher até transbordar. $O$ transbordamento corresponde à incapacidade de efetuar o processamento de forma adequada, o que, no caso do intérprete, se manifesta com a perda da qualidade da interpretação (mais erros) e/ou perda de conteúdo.

O tradutor tem a faculdade de fechar temporariamente a torneira de entrada, dedicando toda a sua capacidade de processamento ao problema que o interessa no momento. O intérprete pode administrar somente o fluxo de saída. Se o reduzir de forma excessiva para direcionar sua capacidade de processamento a um problema específico, verá subir o nível da água.

Atkinson (2006) também diferencia a tradução da interpretação com base na interação entre o tradutor/intérprete e a suas "contrapartes" (termo meu), entendida como a fonte do original ou como 0 destinatário da tradução/interpretação. O tradutor trabalha encapsulado, não estando sujeito, pelo menos no momento da tradução, à reação de uma contraparte, seja ela o cliente, o redator do original ou terceiros que tenham acesso ao original ou à tradução. O intérprete imediatamente percebe a reação do orador ou da plateia à sua interpretação. Isso se dá, por exemplo, quando o público não ri de uma piada mal interpretada ou, na interpretação na modalidade consecutiva, quando alguém confronta o intérprete criticando sua atuação.

Uma terceira diferença reside na necessidade que o intérprete tem de usar a fala. O tradutor "escreve, mas não fala", sendo concebível que uma pessoa totalmente surda-muda se torne excelente tradutora. $O$ intérprete naturalmente não o pode ser e tampouco pode dispensar a visão, que é essencial para a "sighttranslation", para a consulta às notas tomadas na interpretação consecutiva $^{4}$, para a leitura do material apresentado ao público pelo orador e para acompanhar as reações do público e a expressão facial e gestual do orador.

\footnotetext{
${ }^{4}$ Tais modalidades de interpretação serão explicadas na Seção 2.1.2.
} 


\subsubsection{Modalidades de interpretação}

No contexto da interpretação, denomina-se "língua A" o idioma materno do intérprete ou aquele no qual tenha proficiência equivalente. A “língua B" é aquela na qual o intérprete é fluente, sem que seja a sua língua $A$, ea "língua C" é um idioma que o intérprete compreende muito bem (TAYLOR-BOULADON, 2011).

Idiomas ativos são aqueles para os quais o intérprete interpreta, ou seja, as línguas $\mathrm{A}$ e $\mathrm{B}$. O idioma passivo é aquele a partir do qual o intérprete interpreta. Imagine-se um brasileiro que tenha por idioma materno o português (língua $A$ ), sendo fluente em inglês (língua $B$ ) e tendo excelente compreensão do espanhol (língua C). Nesse caso, o intérprete terá por idiomas ativos o português e o inglês, sendo o espanhol seu idioma passivo (TAYLOR-BOULADON, 2011; JONES, 2002).

Diferentes autores reconhecem diferentes modalidades de interpretação. Jones (2002), por exemplo, menciona duas.Na interpretaçãoconsecutiva, o intérprete ouve, calado, o orador por certo tempo, uns poucos minutos, e depois, à frente do público, reconstrói o discurso do orador em outro idioma, provavelmente com a ajuda de notas, enquanto o orador permanece em silêncio, um falando consecutivamente ao outro. $\mathrm{Na}$ interpretação simultânea, o intérprete, instalado numa cabine fechada equipada com um transmissor de som, fala ao mesmo tempo em que o orador, sendo a sua interpretação captada por quem utilizar um receptor (headset).

Jones vê na interpretação sussurrada, conhecida pelo seu nome francês,chuchotage, uma variante da simultânea: 0 intérprete fala simultaneamente ao orador, em voz baixa, diretamente no ouvido do interlocutor, sem o auxílio de qualquer equipamento.

A interpretação simultânea é a modalidade tipicamente utilizada em conferências, sendo por isso frequentemente também chamada de interpretação de conferências ${ }^{5}$.A consecutiva é utilizada em eventos menores ou em caso de falha do equipamento de transmissão/recepção.

\footnotetext{
${ }^{5}$ No Brasil, os organizadores de eventos tais como congressos e conferências frequentemente se referem à interpretação simultânea como "tradução simultânea", chegando a se referir ao "headset" utilizado para ouvir a interpretação como "tradutor".
} 
Phelan (2001) lista 11 modalidades, incluindo a transcrição e a tradução de gravações feitas pelo policial ("wiretappingandtape transcription") e a "tradução à vista" ("sighttranslation”), na qual o intérprete traduz em voz alta um documento que possivelmente nunca viu antes.

Para Passos (2009) a "sighttranslation" é uma modalidade de tradução, não de interpretação: "A literatura sobre Interpretação costuma defini-la como tradução oral de um discurso oral, em oposição à tradução oral de textos escritos"(grifo meu).

Nejm (2011) cita quatro modalidades, entre as quais a interpretação de acompanhamento ("liaison"), na qual o intérprete media o diálogo entre um pequeno grupo de pessoas, sem o uso de equipamento ou anotações.

Mikkelson (1999a) enumera nada menos do que 13 modalidades, incluindo a interpretação de tribunal ("courtinterpreting"), a interpretação telefônica ("overthe-phoneinterpreting") e a interpretação comunitária ("communityinterpreting").

A NationalAssociationofJudiciarylnterpretersandTranslators dos EUA (NAJIT, 2006) enumera apenas três modalidades: simultânea, consecutivae "sighttranslation".

\subsection{A tradução/interpretaçãopública}

A legislação brasileira determina que, para fins oficiais, documentos e depoimentos em idioma estrangeiro sejam traduzidos para o vernáculo,e viceversa,por profissionais credenciados, popularmente chamados de "tradutores juramentados", mas cujo título correto é Tradutor Público e Intérprete Comercial (TPIC). O ofício de TPIC é regulado pelo Decreto 13.609, de 21/10/43, cujos principais dispositivos serão discutidos mais abaixo ${ }^{6}$. A Instrução Normativa 17

\footnotetext{
${ }^{6}$ O Decreto de 5 de setembro de 1991 (sem número) revogou milhares de decretos promulgados entre 1889 e 1991, dos quais quatro tiveram sua vigência posteriormente restabelecida. O Decreto 13.609 fazia parte do rol dos normativos inicialmente revogados, tendo sido restabelecido pelo Decreto de 22 de junho de 1993 (também sem número). Assim, o ofício de Tradutor Público e Intérprete Comercial ficou sem regulamentação por um período de aproximadamente 21 meses. Registre-se, também, que desde dezembro de 2013 tramita na Câmara dos Deputados o Projeto de Lei 68892013 que, em síntese, pretende obrigar todas as Juntas Comerciais a realizarem concursos para TPIC a cada cinco anos, com pelos menos cinco vagas para cada um dos idiomas inglês, francês, espanhol, italiano e alemão. $O$ projeto também prevê a revogação do Decreto 13.609, dando ao Poder Executivo prazo de 60 dias para regulamentar os demais aspectos do ofício de TPIC. Em outras palavras, esse projeto,
} 
do Departamento de Registro Empresarial e Integração, de 05/12/13, complementa o decreto, detalhando-o no que tange a habilitação, nomeação e matrícula do TPIC (vide a nota de rodapé № 8 abaixo).

A legislação faz certa confusão com a denominação desses profissionais, até ignorando a distinção entre tradutores e intérpretes. A Consolidação das Leis do Trabalho (CLT), por exemplo, determina que (grifo meu):

Art. 328 - Só poderão ser admitidos a registro os diplomas, certificados de diplomas, cartas e outros títulos, bem como atestados e certificados que estiverem na devida forma e cujas firmas hajam sido regularmente reconhecidas por tabelião público e, sendo estrangeiros, pela Secretaria do Estado das Relações Exteriores, acompanhados estes últimos da respectiva traducão, feita por intérpretecomercial brasileiro.

Já o art. 819 diz que "[o] depoimento das partes e testemunhas que não souberem falar a língua nacional será feito por meio de intérprete nomeado pelo juiz ou presidente".(grifo meu)

O Código de Processo Civil estabelece (grifo meu):

Art. 151. O juiz nomeará intérprete toda vez que o repute necessário para:

I - analisar documento de entendimento duvidoso, redigido em língua estrangeira;

II - verter em português as declarações das partes e das testemunhas que não conhecerem o idioma nacional;

$[\cdots]$

Art. 153. O intérprete, oficial ou não, é obrigado a prestar o seu ofício, aplicandose-lhe o disposto nos arts. 146 e 147.

Art. 157. Só poderá ser junto aos autos documento redigido em língua estrangeira, quando acompanhado de versão em vernáculo, firmada por tradutor juramentado.

Art. 585. São títulos executivos extrajudiciais: (Redação dada pela Lei no 5.925 , de 1…10.1973)

$[\cdots]$

VI - o crédito de serventuário de justiça, de perito, de intérprete, ou de tradutor, quando as custas, emolumentos ou honorários forem aprovados por decisão judicial; (Redação dada pela Lei no 11.382, de 2006).

$[\ldots]$

se aprovado, "desmontaria" o ofício como ele hoje existe sem dizer o que surgiria em seu lugar. E enquanto o Executivo não editar a nova legislação, não haveria regulamentação alguma. O projeto nada diz sobre os TPIC já nomeados, se permaneceriam nos respectivos cargos ou não.

${ }^{7}$ Neste caso específico, a nomenclatura discrepante talvez se deva ao fato de que a CLT precedeu o Decreto 13.609 em cerca de 5 meses. 
O Código Penal faz sempre referência a "tradutor ou intérprete" (art. 343, 343 e 357) e o Código de Processo Penalprevê que (grifo meu):

Art. 236. Os documentos em língua estrangeira, sem prejuízo de sua juntada imediata, serão, se necessário, traduzidos por tradutor público, ou, na falta, por pessoa idônea nomeada pela autoridade.

Finalmente, a Lei de Arbitragem diz (grifo meu):

Art. 37. A homologação de sentença arbitral estrangeira será requerida pela parte interessada, devendo a petição inicial conter as indicações da lei processual, conforme 0 art. 282 do Código de Processo Civil, e ser instruída, necessariamente, com:

I - o original da sentença arbitral ou uma cópia devidamente certificada, autenticada pelo consulado brasileiro e acompanhada de tradução oficial;

II - o original da convenção de arbitragem ou cópia devidamente certificada, acompanhada de tradução oficial.

Em suma, nos normativos acima mencionados, o indivíduo que presta serviços oficiais de interpretação ou tradução é chamado de intérprete/tradutor sem outra qualificação, intérprete/tradutor comercial, juramentado, público ou oficial. Para os fins do presente trabalho, adotarei a abreviação do nome completo (TPIC) em referência ao indivíduo e a expressão "tradução/interpretação pública" em referência ao serviço.

Nos termos do Decreto 13.609, os TPIC, que não são servidores públicos, são selecionados por concurso e nomeados pela Junta Comercial de cada Unidade da Federação ${ }^{8}$ (art $1^{\circ}$ ). O concurso compreenderá:

\footnotetext{
${ }^{8}$ Segundo a Lei 8.934 , de 18/11/94, o Sistema Nacional de Registro de Empresas Mercantis (Sinrem) é composto por um órgão central, o Departamento Nacional de Registro do Comércio (DNRC) e por "órgãos locais, com funções executora e administradora dos serviços de registro" (art. $3^{\circ}$ ), havendo um em cada estado e no Distrito Federal. Às Juntas Comerciais cabe, entre outras funções (art. 9 e 32): (i) conceder e cancelar a matrícula de leiloeiros, tradutores públicos e intérpretes comerciais, trapicheiros e administradores de armazéns-gerais; (ii) arquivar (a) documentos de constituição, alteração, dissolução e extinção de firmas mercantis individuais, sociedades mercantis e cooperativas; (b) atos relativos a consórcio e grupo de sociedade de que trata a Lei das Sociedades Anônimas; (c) atos concernentes a empresas mercantis estrangeiras autorizadas a funcionar no Brasil; (d) declarações de microempresa; e (e) outros atos; (iii) autenticar instrumentos de escrituração das empresas mercantis registradas e dos agentes auxiliares do comércio; (iv) elaborar a tabela de preços de seus serviços; e (v) processar a habilitação e a nomeação dos tradutores públicos e intérpretes comerciais. O Decreto 8.001, de 10/05/13, extinguiu o DNRC, substituindo-o pelo Departamento de Registro Empresarial e Integração (DREI), vinculado à Secretaria da Micro e Pequena Empresa da Presidência da República. Criou-se, assim, uma situação esdrúxula, na qual, sem menção direta à Lei 8.934, um decreto determinou que uma estrutura responsável por micro e pequenas empresas trate também das empresas de grande porte e das sociedades por ações. A parte ficou responsável pelo todo.
} 
a) prova escrita constando de versão, para o idioma estrangeiro, de um trecho de 30 ou mais linhas, sorteado no momento, de prosa em vernáculo, de bom autor; e tradução para o vernáculo de um trecho igual, preferencialmente de cartas rogatórias, procurações, cartas partidas, passaportes, escrituras notariais, testamentos, certificados de incorporação de sociedades anônimas e seus estatutos;

b) prova oral, consistindo em leitura, tradução e versão, bem como em palestra, com arguição no idioma estrangeiro e no vernáculo que permitam verificar se o candidato possui o necessário conhecimento e compreensão das sutilezas e dificuldades de cada uma das línguas.

As notas irão de zero a dez, sendo considerados aprovados os candidatos com resultado igual ou superior a sete (art. $\left.6^{\circ}\right)$.Os critérios de avaliação da prova oral do último concurso promovido em 2009 pela Junta Comercial do Estado do Rio de Janeiro (JUCERJA), foram ${ }^{9}$ :

Tabela 1 - Avaliação da prova oral do concurso de 2009 para TPIC da JUCERJA

\begin{tabular}{|l|c|}
\hline Item & Valor \\
\hline Clareza durante a exposição & 1,0 \\
\hline Objetividade ao apresentar as ideias & 1,0 \\
\hline Pronúncia correta & 2,0 \\
\hline Entonação adequada & 1,0 \\
\hline Adequação ao tema tratado & 1,0 \\
\hline Traduc̃ão apropriada (correta) & 2,0 \\
\hline Versão apropriada (correta) & 2,0 \\
\hline
\end{tabular}

Fonte: Edital JUCERJA oㅜ 01/2009

As funções dos TPIC compreendem (art. 17)(grifo meu):

a) Passar certidões, fazer traduções em língua vernácula de todos os livros, documentos e mais papeis escritos em qualquer língua estrangeira, que tiverem de ser apresentados em Juízo ou qualquer repartição pública federal, estadual ou municipal ou entidade mantida, orientada ou fiscalizada pelos poderes públicos e que para as mesmas traduções Ihes forem confiados judicial ou extrajudicialmente por qualquer interessado;

b) Intervir, quando nomeados judicialmente ou pela repartição competente, nos exames a que se tenha de proceder para a verificação da exatidão de qualquer tradução que tenha sido arguida [...];

c) Interpretar e verter verbalmente em língua vulgar, quando também para isso forem nomeados judicialmente, as respostas ou depoimentos dados em Juízo por estrangeiros que não falarem o idioma do país e no mesmo Juízo tenham de ser interrogados como interessados, como testemunhas ou informantes, bem assim, no foro extrajudicial, repartições públicas federais, estaduais ou municipais;

d) Examinar, quando solicitada pelas repartições públicas fiscais ou administrativas competentes ou por qualquer autoridade judicial, a falta de exatidão com que for impugnada qualquer tradução feita por corretores de navios, dos manifestos e documentos que as embarcações estrangeiras tiverem de apresentar para despacho nas Alfândegas, bem assim qualquer tradução feita em

9 A prova escrita do idioma inglês está disponível em http://site.pciconcursos.com.br/provas/12993861/1e15e5bdc2aa/jcrj09_ingl_prova_01.pdf . Acesso em 23/04/14. 
razão de suas funções por ocupantes de cargos públicos de tradutores e intérpretes.

O Decreto estabelece a obrigatoriedade geral do recurso a um TPIC para que um documento ou declaração seja aceitável para fins oficiais ou judiciais:

Art. 18. Nenhum livro, documento ou papel de qualquer natureza que for exarado em idioma estrangeiro, produzirá efeito em repartições da União dos Estados e dos municípios, em qualquer instância, Juízo ou Tribunal ou entidades mantidas, fiscalizadas ou orientadas pelos poderes públicos, sem ser acompanhado da respectiva tradução feita na conformidade deste regulamento.

Parágrafo único. Estas disposições compreendem também os serventuários de notas e os cartórios de registro de títulos e documentos que não poderão registrar, passar certidões ou públicas-formas de documento no todo ou em parte redigido em língua estrangeira.

Art. 19. A exceção das traduções feitas por corretores de navios, dos manifestos e documentos que as embarcações estrangeiras tiverem de apresentar para despacho nas Alfândegas e daquelas feitas por ocupantes de cargos públicos de tradutores ou intérpretes, em razão de suas funções, nenhuma outra terá fé pública $^{10}$ se não for feita por qualquer dos tradutores públicos e intérpretes comerciais nomeados de acordo com o presente regulamento.

O ofício de TPIC é pessoal, podendo ser delegado, sob licença, apenas em caso de doença contraída após a nomeação (art. 14). Contudo, em caso de falta ou impedimento dos TPIC e dos seus prepostos, admite-se a nomeação de "tradutores e intérpretes ad-hoc"11 (art. 19, § único).

As Juntas Comerciais determinarão o número de TPIC para cada idioma, admitindo-se a habilitação em mais de uma língua, e as tabelas de emolumentos $^{12}$, sendo expressamente vedado aos TPIC oferecer quaisquer descontos sobre os emolumentos nelas fixado (art. 29, 30 e 35, § único).

Segundo o site da JUCERJA, hoje há no estado $144^{13}$ TPIC cobrindo os seguintes idiomas:

\footnotetext{
${ }^{10}$ Autoridade que dá veracidade às declarações ou documentos emitidos por certa pessoa. No caso, isso significa que a tradução ou interpretação feita por um TPIC é aceita como verdadeira até prova em contrário.

${ }_{11}^{11}$ Expressão latina que significa "para isto", "para este caso".

${ }^{12}$ Taxas auferidas pelo exercício de uma função pública.

13 Disponível em <http://www.jucerja.rj.gov.br/Servicos/Tradutores/>. Acesso em 20/04/14. O site na verdade lista 146 TPIC, dos quais dois já faleceram, segundo informação dada pela Associação Profissional de Tradutores Públicos e Intérpretes Comerciais, Juramentados, do Estado do Rio de Janeiro (ATP-Rio).
} 
Tabela 2- TPIC no Estado do Rio de Janeiro

\begin{tabular}{|c|c|c|}
\hline Idioma & No de TPIC & \\
\hline Inglês & 62 & $40 \%$ \\
\hline Francês & 25 & $16 \%$ \\
\hline Alemão & 24 & $16 \%$ \\
\hline Espanhol & 16 & $10 \%$ \\
\hline Italiano & 10 & $6 \%$ \\
\hline Japonês & 4 & $3 \%$ \\
\hline Árabe & 2 & $1 \%$ \\
\hline Hebraico & 2 & $1 \%$ \\
\hline Neerlandês & 2 & $1 \%$ \\
\hline Polonês & 2 & $1 \%$ \\
\hline Tcheco & 2 & $1 \%$ \\
\hline Finlandês & 1 & $1 \%$ \\
\hline Latim & 1 & $1 \%$ \\
\hline Mandarim & 1 & $1 \%$ \\
\hline Total & $\mathbf{1 5 4}$ & $\mathbf{1 0 0} \%$ \\
\hline
\end{tabular}

O somatório da tabela anterior é superior a 144porque alguns TPIC estão habilitados para mais de um idioma:

Tabela 3- № de idiomas por TPIC
\begin{tabular}{|c|c|}
\hline № Idiomas & Qtde. TPIC \\
\hline 3 & 3 \\
2 & 4 \\
\hline 1 & 137 \\
\hline Total & $\mathbf{1 4 4}$ \\
\hline
\end{tabular}

A pouca quantidade de TPIC com habilitação dupla ou tripla certamente foi influenciada pelo fato de que, quando da realização do último concurso, em 2009, todas as provas ocorreram simultaneamente, impossibilitando que um candidato tentasse se habilitar para mais de um idioma.

Os últimos concursos para provimento do ofício de TPIC no Estado do Rio de Janeiro foram realizados em 1983 e 2009. Dado o intervalo de 26 anos, não surpreende que $40 \%$ dos atuais TPIC tenham obtido suas matrículas em $2010^{14}$. As matrículas em anos em que não houve concurso se devem a transferências de TPICsde outras Unidades da Federação. As matrículas podem ser canceladas pela transferência do TPIC para outras Unidades da Federação e também pela sua renúncia ou morte.

\footnotetext{
${ }^{14} \mathrm{O}$ resultado do concurso foi publicado no Diário Oficial em 07/01/10.
} 
Gráfico 1-TPIC matriculados a cada ano

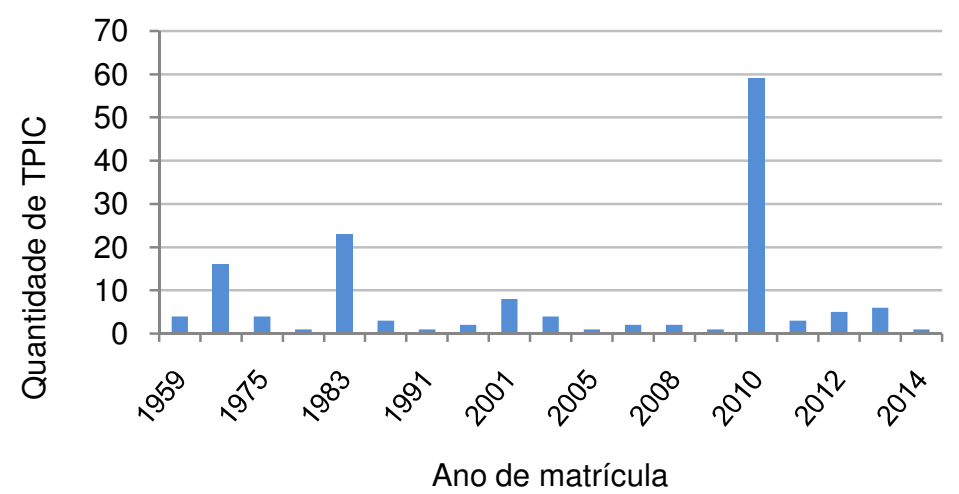

\subsection{A interpretação de tribunal}

\subsubsection{Denominação e modalidades}

Não há um nome consagrado para a interpretação feita no contexto do direito, que pode se dar tanto dentro de um tribunal, durante uma audiência, quanto fora, por exemplo, em um presídio, no ato da leitura da denúncia a um réu preso ${ }^{15}$.

Pagura (2010) utiliza a expressão "interpretação jurídica". Segundo o Dicionário Houaiss, o adjetivo "jurídico" significa "relativo ao direito", o que dá à expressão utilizada por Pagura uma amplitude que excede o objeto deste trabalho. A interpretação "jurídica" transcende o Judiciário, abarcando, por exemplo, a comunicação entre advogados que representem as várias partes de um negócio ou entre advogados e seus clientes. Até mesmo a interpretação da cerimônia de casamento entre brasileiro e estrangeiro - ou entre estrangeiros, se realizada no País - poderia ser considerada "jurídica".

O adjetivo "jurídico" poderia talvez ser substituído por "legal”, mas essa opção não resolveria a questão da amplitude e ainda poderia gerar confusãocom o sentido de "lícito", em contraste a ilegal/ilícito.

O adjetivo "forense"(PASSOS 2009; REIS, 2013), que o Dic. Houaiss define como "relativo aos tribunais e à justiça", apesar de mais restrito do que "jurídico", ainda é por demais amplo. Os sinônimos "judicial" e "judiciária" teriamo

\footnotetext{
${ }^{15}$ A denúncia é a etapa inicial do processo penal. Segundo o art. 41 do CPP, ela "conterá a exposição do fato criminoso, com todas as suas circunstâncias, a qualificação do acusado ou esclarecimentos pelos quais se possa identificá-lo, a classificação do crime e, quando necessário, o rol das testemunhas".
} 
mesmo problema. A interpretação de um depoimento em delegacia policial, por exemplo, poderia ser classificada como "forense", "judicial” ou “judiciária".

Como o presente estudo se limita à interpretação feita em juízo, parece-me mais adequada a designação "interpretação de tribunal" (GINEZI, 2012; NOVAIS NÉTO, 2009),que se refere ao círculo concêntrico interior da Figura 1, de escopo mais restrito. Naturalmente, o intérprete não estará necessariamente na sala de audiência. A interpretação do diálogo entre o réu e o advogado de defesa ou defensor público em sala contígua, por exemplo, também é "de tribunal", porque ocorre no âmbito de uma audiência judicial. A crítica de Reis (2013) de que a palavra "tribunal" no Brasil evoca os juízos de segunda instância não me parece relevante no presente contexto ${ }^{16}$.

Figura 1- A interpretação no contexto do Direito

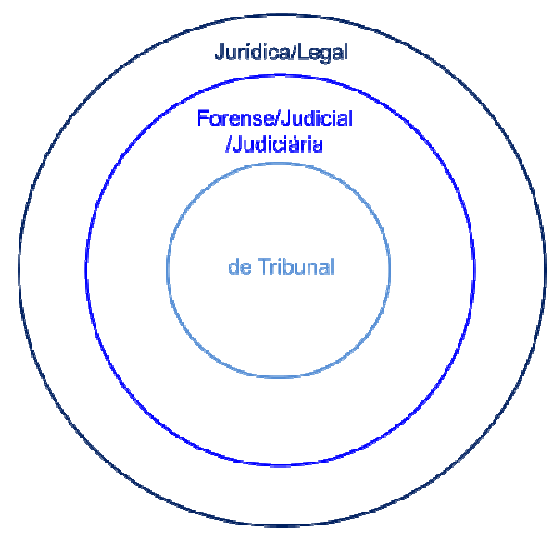

A Classificação Brasileira de Ocupações ${ }^{17}$ (CBO) reconhece as profissões de tradutor e intérprete dentro da "família ocupacional" 2614: "Filólogos, tradutores, intérpretes e afins", listando como sinônimos de intérprete as ocupações "Intérprete comercial; Intérprete de comunicação eletrônica; Intérprete de conferência; Intérprete simultâneo; Tradutor simultâneo". Não há menção a intérpretes jurídicos, legais, forenses, judiciais, judiciários ou de tribunal, mas consta "tradutor público juramentado" na lista de sinônimos de "tradutor".

\footnotetext{
${ }^{16}$ Essa observação advém do fato de os juízos de segunda instância serem chamados de "Tribunais de Justiça", no caso da Justiça Estadual, e de "Tribunais Regionais Federais" no caso da Justiça Federal, enquanto os de primeira instância são denominados "varas". Reis não menciona o fato de que os juízos de terceira instância também têm a palavra "tribunal" em seu nome. Veja-se, por exemplo, o Superior Tribunal de Justiça e o Supremo Tribunal Federal.

17 A CBO é "o documento normalizador [...] da nomeação e da codificação [...] das ocupações do mercado de trabalho brasileiro. É ao mesmo tempo uma classificação enumerativa e uma classificação descritiva [...] sem função de regulamentação profissional." (MTE, 2010)
} 
Diga-se de passagem que a CBO informa ser necessário ensino médio ou técnico aos tradutores e intérpretes e superior completo para filólogos e linguistas e, em todos os casos, mais de cinco anos de experiência para o exercício pleno das atividades.

Reis (2013) relata conversa informal com uma ex-presidente do Sindicato Nacional dos Tradutores (SINTRA) na qual esta the informou que o sindicato havia tentado, sem sucesso, "regulamentar a profissão" de intérprete de tribunal, chamado por Reis de "forense".

Quanto às modalidades de interpretação, utilizam-se a consecutiva, a sussurrada (para o réu) e a "sighttranslation" de documentos (p. ex., a leitura da sentença). Desconheço o uso de interpretação simultânea em tribunais brasileiros.

\subsubsection{Regulamentação e orientações}

Independentemente da confusão geral quanto à nomenclatura aplicável ao tradutor público, discutida na Seção 2.2, e da indefinição acerca da designação do intérprete que atua no âmbito dos tribunais, resta claro que a legislação brasileira determina a obrigatoriedade do recurso a um intérprete quando as partes e as testemunhas de um processo judicial não falarem o português.

Além dos já citados art. 151 do CPC e art. 819 da CLT,cabe também mencionar os art. 193 e 223 do CPP:

Art. 193. Quando o interrogando não falar a língua nacional, o interrogatório será feito por meio de intérprete.

Art. 223. Quando a testemunha não conhecer a língua nacional, será nomeado intérprete para traduzir as perguntas e respostas.

$(\ldots)$

Note-se que tantoo Decreto 13.609 quanto o CPP dizem ser necessário interpretar as perguntas feitas a pessoas que não falem o português e as respostas por elas dadas, omitindo-se em relação a todo o resto da audiência. $A$ legislação não determina, portanto, a interpretação para o idioma do réu estrangeiro dos depoimentos dados por falantes do português e de qualquer 
diálogo que haja entre juiz, advogado de defesa ou defensor público e o procurador do Ministério Público Federal ${ }^{18}$.

Cabe ressaltar que a Justiça tipicamente aceita a ausência de intérprete para o idioma materno do réu ou mesmo de qualquer intérprete se ficar demonstrado que o réu compreendia o idioma "intermediário" utilizado pelo intérprete (p.ex., o inglês) ou o português ${ }^{19}$.

OPlano de Gestão para o Funcionamento de Varas Criminais e de Execução Penal elaborado em 2009 pelo Conselho Nacional de Justiça $(\mathrm{CNJ})^{20}$, cujo objetivo é "apontar sugestões quanto às ações proativas do juiz para tornar célere e efetiva a prestação jurisdicional”, reconhece o problema(grifo meu):

A experiência tem demonstrado que nas ações penais movidas em desfavor de réu estrangeiro ocorre certo constrangimento aos acusados, caracterizado, por vezes, em razão do seu alheamento quanto ao cerne da acusação.

\section{$[\ldots]$}

Imperativo estabelecer-se, por meio de entendimento entre o Judiciário e o Ministério Público, como rotina nas ações penais em que figure como acusado pessoa de nacionalidade estrangeira, apresente o órgão de acusação resumo da peça acusatória em linguagem coloquial, de preferência com tradução para a língua de domínio do acusado, cientificando o acusado do quê e por que está sendo acusado; qual a pena prevista e a cronologia do processo até a prolação da sentença.

Dado o espírito das observações acima, não faz sentido crer que a expressão "de preferência" indique que a tradução da peça acusatória seja apenas recomendável e não "imperativa". O únicoentendimentológico no contexto é que a preferência se relacione não à tradução, mas à "língua de domínio do acusado", sendo essa outra expressão obscura. Não se tendo

\footnotetext{
${ }^{18} \mathrm{O}$ art. 127 da Constituição Federal define o Ministério Público (MP) como sendo uma "instituição permanente, essencial à função jurisdicional do Estado, incumbindo-lhe a defesa da ordem jurídica, do regime democrático e dos interesses sociais e individuais indisponíveis". Ele representa a sociedade e por isso, tem completa autonomia funcional e administrativa, não fazendo parte de nenhum dos Poderes do Estado, nem mesmo do Judiciário. Entre várias outras tarefas, cabe ao MP promover as ações penais no papel de acusador.

${ }^{19}$ Pesquisa da jurisprudência ( $2^{\underline{a}}$ e $3^{\underline{a}}$ instâncias) do Supremo Tribunal Federal, (STF) do Superior Tribunal de Justiça (STJ) e do Tribunal Regional Federal da $2^{\mathrm{a}}$ Região - TRF-2 (Estados do Rio de Janeiro e do Espírito Santo) cobrindo as decisões publicadas entre 01/01/2009 e 30/04/2014 no site da Justiça Federal: <http://www.jf.jus.br/juris/unificada/>. Identificadas as seguintes ações: no STF, nenhuma; no STJ: Recurso em Habeas Corpus 26.080, Habeas Corpus 123.389, 130.485 e 198.203; no TRF-2: Habeas Corpus 9.046; Apelação Criminal 7.778, 11.071 e 11.190 .

${ }_{20}$ Como explica o seu próprio site, "[o] Conselho Nacional de Justiça (CNJ) é uma instituição pública que visa aperfeiçoar o trabalho do sistema judiciário brasileiro, principalmente no que diz respeito ao controle e à transparência administrativa e processual." Disponível em < http://www.cnj.jus.br/sobre-o-cnj>. Acesso em 29/05/14.
} 
utilizado a expressão clássica "língua natal", é de se supor que o Plano admita a tradução para um terceiro idioma. Assim, é "imperativo" que a peça acusatória seja traduzida para um idioma que o réu entenda, de preferência, muito bem("domine").

Espantosamente, o Plano a seguir considera "recomendável" a utilização de "sistema eletrônico de tradução", citando expressamente o Google Translate, "a fim de auxiliar o serviço judicial".

Como resultado do Plano, o CNJ publicou um Manual Prático de Rotinas das Varas Criminais e de Execução Penal que, no caso de réu estrangeiro preso, diz(grifo meu):

Rotina: para auxiliar na compreensão da acusação, poderá o Ministério Público efetuar, no idioma de fluência do acusado, um resumo da acusação ou a tradução da denúncia, por tradutores próprios, podendo valer-se de recursos junto à Rede Mundial de Computadores (ex.: Google)

Não obstante o Plano reconhecer o problema do alheamento do réu não falante do português, o Manual é omisso quanto à interpretação e timidamente sugere que certos documentos sejam traduzidos. A expressão "tradutores próprios" é significativamente seguida da surpreendente menção a ferramentas de tradução da internet, notoriamente falhas, dando a entender que a tradução poderia ser feita por um membro ou funcionário do próprio Ministério Publico em vez de por tradutor profissional.

Em contatos por e-mail com a Seção do Rio de Janeiro da Ordem dos Advogados do Brasil (OAB), com o SINTRA, e com a ATP-Rio, essas organizações informaram jamais terem editado normas ou recomendações sobre o tema. A Associação dos Juízes Federais do Rio de Janeiro e Espírito Santo não respondeu à minha consulta.

$A O A B$ tem um "Código de Ética e Disciplina" que naturalmente não se aplica a intérpretes, e que passa totalmente ao largo da interpretação de tribunal. O SINTRA e a ATP-Rio não dispõem de código de ética ou documento similar.

A legislação possibilita que, na ausência ou indisponibilidade de um TPIC para o idioma em questão, o juiz convoque outra pessoa, que sequer precisa ser tradutor ou intérprete profissional, a prestar o serviço. Como se verá na Seção 3.2, isso é comum.Novais Néto (2009) menciona a convocação de professores de idiomas estrangeiros das universidades, principalmente as públicas, e o trabalho de Passos (2009) se baseou na sua própria atuação como intérprete 
ad-hoc. Um dos juízes entrevistados para o presente estudo narra que o pai de um Oficial de Justiçada sua Vara "salva a gente em inglês e espanhol".

As Varas Criminais da Seção Judiciária do Rio de Janeiro ${ }^{21}$ pedem ao intérprete que assine um termo de compromisso ou documento semelhante ao atuar em juízo. No curso do presente trabalho, obtive cópias dos modelos utilizados por seis daquelas varas. Trata-se de documentos breves, com pequenas variações na sua redação e que repetem a fórmula central, segundo a qual o intérprete se comprometea cumprir sua tarefa "bem e fielmente, sem dolo nem malícia"22.

Ninguém, incluindo os juízes, sabe precisar a origem dos termos de compromisso utilizados, sendo de se supor que eles se baseiem no art. 159 do CPP, aplicável ao intérprete por força do art. 281:

Art. 159. O exame de corpo de delito e outras perícias serão realizados por perito oficial, portador de diploma de curso superior.

$[\ldots]$

$\S 200$ s peritos não oficiais prestarão o compromisso de bem e fielmente desempenhar o encargo.

$[\ldots]$

Art. 281. Os intérpretes são, para todos os efeitos, equiparados aos peritos.

Em suma, não há nada na legislação que diga como o juiz deve conduzir a atuação do intérprete e tampouco existe qualquer recomendação a respeito da parte do Judiciário ou das entidades de classe. Ademais, mesmo o TPIC não recebe qualquer treinamento ou orientação para atuar em tribunais ${ }^{23}$ e a interpretação em tribunal é frequentemente feita por pessoas sem nenhum treinamento de interpretação, cuja única qualificação é o conhecimento do idioma em questão, real ou suposto. As únicas obrigações que o intérprete assume, por meio do termo de compromisso, são as de precisão ("bem e fielmente") e de boa fé ("sem dolo nem malícia").

\footnotetext{
${ }^{21}$ Vide breve explicação sobre a organização da Justiça Federal na Seção 3.1.

${ }^{22} \mathrm{Na}$ Apelação Criminal 6843, o TRF-2 considerou que "a ausência de termo de compromisso assinado pelo intérprete é mera irregularidade formal", rejeitando o argumento de que "a falta dessa formalidade [causara] prejuízo à defesa do ora acusado".

${ }^{23}$ Em carta datada de 04/04/14 e circulada aos seus associados por e-mail, a Presidente da ATP-Rio informa que a associação pretende desenvolver um "manual de interpretação em audiência e curso dirigido".
} 
Em contraste com o Brasil, a atuação dos intérpretes de tribunal é regulada nos EUA por lei federal de 1978 e vários estados norte-americanos depois criaram processos de certificação, começando com a Califórnia, em 1979, seguida de Nova lorque (1980), do Novo México (1985) e de Nova Jérsei (1987). A Austrália passou a exigir certificação de proficiência também em 1978, e o Canadá, no começo da década de 1980. (MIKKELSON, 1999a)

Além disso, a NationalAssociationofJudiciaryInterpretersandTranslators dos EUA (NAJIT) publicou um "Código de Ética e Responsabilidades Profissionais" (tradução minha do título) que apresenta os oito "cânones" aplicáveis aos seus membros: precisão, imparcialidade, confidencialidade, limitação da atuação, protocolo e comportamento, manutenção e aperfeiçoamento das habilidades e do conhecimento, correta apresentação de credenciais e impedimentos.

Finalmente, o Judiciário dos EUA publicou um“Manual de orientação e Glossário para Intérpretes dos Tribunais Federais" (ADM.OFFICE OF THE US COURTS, 2014; tradução minha do título) que descreve a estrutura daquele Poder, o andamento dos processos, as modalidades de interpretação ${ }^{24}$ e as obrigações do intérprete. Trata-se de um documento extenso e detalhado, que, como o título indica, inclui um glossário e croquis das salas de audiência com a indicação dos locais onde o intérprete pode se acomodar.

\subsubsection{Remuneração}

Como se verá na Seção 3.2, a (má) remuneração dadas aos intérpretes pela Justiça Federal foi um aspecto frequentemente mencionado nas entrevistas, o que justifica a sua análise em profundidade.

A Deliberação no 55/2012 da JUCERJA, de 09/04/12, prevê emolumentos de $R \$ 374$ para a primeira hora de interpretação e de $R \$ 94$ para cada quarto de hora subsequente. Como $374 \div 4=93,5$, as horas adicionais custam aproximadamente $0,5 \%$ mais do que a primeira hora. Além disso, a contagem das horas se inicia na hora marcada para o ato e são devidos $50 \%$ dos emolumentos caso o intérprete tenha comparecido e o ato seja cancelado. Em qualquer hipótese, são devidos emolumentos equivalentes a uma hora.

\footnotetext{
${ }^{24}$ As mesmas três da NAJIT: simultânea, consecutiva e "sighttranslation".
} 
A tabela de valores de referência do SINTRA ${ }^{25}$ sugere preços para a tradução/interpretação não pública, não mencionando especificamente a interpretação de tribunal. Assim, para os fins deste estudo se consideraram os honorários indicados para a interpretação de conferências na modalidade consecutiva na praça do Rio de Janeiro: $R \$ 1.777$ para serviços prestados em inglês, espanhol ou francês. A tabela determina que os demais idiomas, por serem considerados raros, estão sujeitos a outros preços, sem, porém, especificá-los, devendo eles presumivelmente serem superiores e ajustados pelo intérprete e pelo cliente.

Os honorários se aplicam a serviços com até duas horas de duração. Como a tabela não estabelece valores para horas-extra de interpretação consecutiva, aqui se considerou a sobretaxa de $50 \%$ aplicável às horas-extra dos serviços de interpretação simultânea. Os $\mathrm{R} \$ 1.777$ pela jornada de duas horas correspondem a $\mathrm{R} \$ 888,50$ por hora, que, com a sobretaxa de $50 \%$, resultariam em honorários teóricos de $\mathrm{R} \$ 1.332,75$ por hora-extra ${ }^{26}$.

Em total descompassocom o art. 35 do já mencionado Decreto 13.609, que regula o ofício de TPIC, a Resolução no 558 do Conselho da Justiça Federal ${ }^{27}$, de 22/05/07, estabelece honorários de $R \$ 58,70$ para a interpretação em audiências/sessões com até três horas de duração e de $\mathrm{R} \$ 23,48$ por hora excedente, admitindo-se que esses valores sejam triplicados pelo juiz em

\footnotetext{
${ }^{25}$ http://www.sintra.org.br/site/index.php?p=c\&pag=preços. Acesso em: 20/04/14.

${ }^{26} \mathrm{O}$ site do SINTRA diz que que uma hora-extra custa $\mathrm{R} \$ 350$, com suposta sobretaxa de $25 \%$ sobre o preço "normal", e que duashoras-extra custam $\mathrm{R} \$ 700$, com sobretaxa de $50 \%$.Ora, como $2 \times 350=700$, de início já se vê que a sobretaxa é sempre a mesma.Como a Diretoria do SINTRA me afirmou por e-mail estarem corretos os valores absolutos de $R \$ 350$ e $R \$ 700$, resulta estar errada pelo menos uma das sobretaxas. De fato, para chegar ao valor unitário de $\mathrm{R} \$ 350$ para cada hora-extra, o SINTRA multiplicou o preço de $\mathrm{R} \$ 1.400$ para a jornada de 6 horas da interpretação simultânea por 0,25 $(1.400 \times 0,25=350)$, tendo erroneamente interpretado isso como se uma hora-extra fosse $25 \%$ mais cara do que uma hora "normal". O preço unitário "normal" é de $\mathrm{R} \$ 233,33$ $(1.400 \div 6)$, cuja diferença absoluta em relação a $R \$ 350$ é de $R \$ 116,67(350-233,33)$, sendo esse valor correspondente a $50 \%$ de $R \$ 233,33(116,67 \div 233,33=0,5)$. Em outras palavras, $233,33 \times 1,5=350$. Veja-se a questão por outro ângulo: multiplicar um valor por 0,25 equivale a dividi-lo por 4 , de modo que 6 horas "normais" custam o mesmo do que 4 horas-extra. Assim, as horas-extra têm preço unitário equivalente a 150\% das horas "normais" $(6 \div 4=1,5)$, indicando que o aumento foi de $50 \%$. Em suma, diferentemente do que diz o site do SINTRA, a sobretaxa aplicada às horas-extra é sempre de $50 \%$.

${ }^{27}$ Como explica o seu próprio site, "[0] Conselho da Justiça Federal (CJF), com sede em Brasília-DF, tem como missão exercer, de forma efetiva, a supervisão orçamentária e administrativa, o poder correicional [a fiscalização] e a uniformização, bem como promover a integração e o aprimoramento da Justiça Federal". Disponível em <http://www.cjf.jus.br/cjf/cjf/o-que-e>. Acesso em 29/05/14.
} 
consequência do grau de especialização do profissional, da complexidade do trabalho e do local de sua realização ${ }^{28}$.

A resolução não entra no mérito da forma de cômputo das horas trabalhadas, sendo de se supor que a contagem comece somente com o início da audiência.

Note-se também que, como o valor das horas adicionais da Justiça Federal corresponde a $40 \%$ do valor da primeira hora, a remuneração do intérprete tem, para usar o jargão econômico, um "viés de baixa": quanto mais tempo durar a audiência, mais o valor horário médio tenderá para o limite inferior ( $R \$ 23,48)$, ou seja, menor ele será. Com a tabela do SINTRA ocorre o inverso: quanto mais longo o evento, maior a remuneração média. No caso dos emolumentos da JUCERJA, dado o aumento irrisório, mero arredondamento, nos emolumentos aplicáveis às horas adicionais, a curva da remuneração tem inclinação imperceptivelmente positiva.

O gráfico a seguir mostra como a remuneração oferecida pela Justiça Federal, mesmo admitindo a triplicação, é muitíssimo inferior àquelas estabelecida pela JUCERJA e recomendada pelo SINTRA.

\section{Gráfico 2- Remuneração do intérprete (SINTRA x JUCERJA x Justiça Federal)}

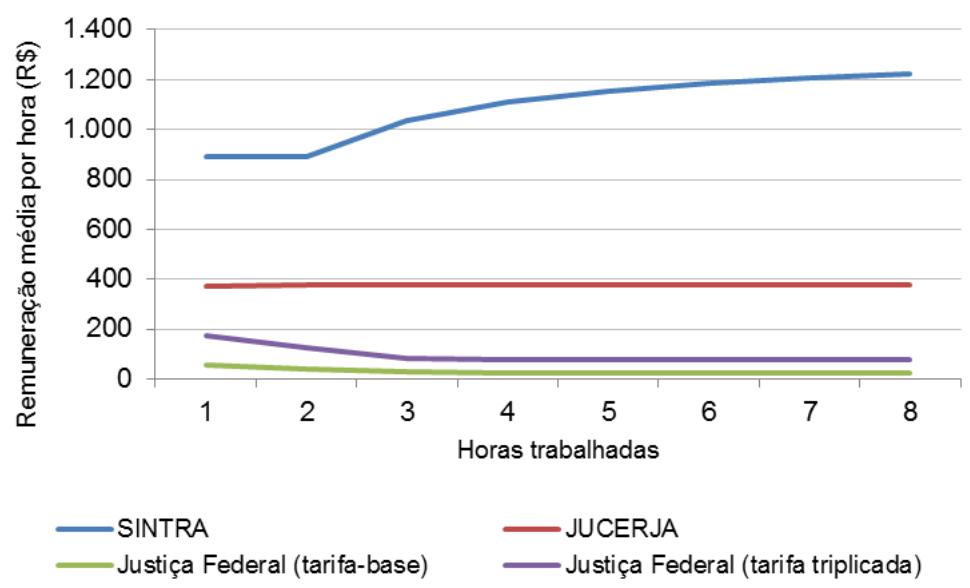

Deve-se observar que a curva referente à remuneração recomendada pelo SINTRA é um construto que muito possivelmente não existe na realidade, sendo impossível saber em que medida os valores previstos na tabela do sindicato são de fato praticados. Por outro lado, o gráfico ignora aspectos não diretamente relacionados aos preços horários, tais como a forma de cálculo da quantidade de

${ }^{28}$ Art. $3^{\circ} \S 1^{\circ}$ e Art. $4^{\circ} \S$ único da mencionada resolução. 
horas trabalhadas, que podem ter impacto significativo na remuneração do intérprete. O fato é que, mesmo ignorada a tabela do SINTRA, os valores praticados pela Justiça Federal, que permanecem constantes há sete anos, são muito inferiores aos emolumentos estabelecidos pela JUCERJA.

Outra forma de analisar a questão reside na comparação da remuneração dos servidores da Justiça Federal com a do intérprete. Um intérprete que trabalhasse oito horas diárias para a Justiça Federal ganharia $\mathrm{R} \$ 223,06$ em um dia $^{29}$. Considerando-se um mês com 22 dias úteis, a remuneração mensal teórica seria de $R \$ 4.907,32$, muito próxima dos vencimentos de $R \$ 4.947,95$ de um Técnico Judiciário classe A-1, conforme a Tabela de Remuneração do Pessoal da Justiça Federal ${ }^{30}$ em vigor desde 01/01/14.

Tais vencimentos incluem o salário-base e a Gratificação Judiciária (GAJ) de $75,2 \%$, ignorados todos os adicionais. Nos termos do art. $13 \S 1^{\circ}$ da Lei 11.416, de 15/12/06, a GAJ passará a $90 \%$ a partir de 01/01/15, fazendo com que a remuneração mensal teórica do intérprete se distancie dos vencimentos do Técnico Judiciário A-1 e se aproxime dos vencimentos de $R \$ 4.771,60$ do cargo imediatamente inferior, Auxiliar Judiciário classe $\mathrm{C}-13^{31}$.

Segundo os art. $4^{\circ}$ e $8^{\circ}$ da mencionada lei, o Técnico Judiciário necessita ter curso de ensino médio, ou curso técnico equivalente, cabendo-lhe a execução de tarefas de suporte técnico e administrativo e ao Auxiliar Judiciário basta o curso de ensino fundamental, cabendo-lhe atividades básicas de apoio operacional.

A Tabela de Remuneração do Pessoal da Justiça Federal contempla 39 cargos, estando o Técnico Judiciário A-1 na 14aㅡ posição e o Auxiliar Judiciário classe $C-13$, na $13^{\underline{a}}$ posição. Apenas para referência, o subsídio ${ }^{32}$ dos juízes federais é de $R \$ 26.589,69$.

O fato de a remuneração mensal teórica do intérprete ser um construto inexistente na prática não invalida a conclusão de que a Justiça Federal dá pouco valor ao seu trabalho, remunerando-o em valores comparáveis aos

\footnotetext{
${ }^{29}$ Soma-se o preço da hora inicial ao valor de sete horas-adicionais: $\mathrm{R} \$ 58,70+(7 \mathrm{x}$ 23,48).

${ }^{30}$ Disponível em <http://www.cjf.jus.br/cjf/gestao-pessoas/administracao-de-rh/tabelasde-remuneracao $>$. Acesso em 20/04/14.

${ }^{31}$ Salário base de $\mathrm{R} \$ 2.511,37$ + GAJ de $90 \%$, não se considerando qualquer reajuste inflacionário.

${ }_{32}$ Conforme Tabela de Subsídios disponível em <http://www.cjf.jus.br/cjf/gestaopessoas/administracao-de-rh/tabelas-de-remuneracao>. Acesso em 20/04/14
} 
vencimentos de servidores em cargos subalternos que não pedem diploma superior. Note-se, ainda, que a comparação acima se fez com base apenas nos vencimentos monetários dos servidores, desprezando benefícios e vantagens tais como férias remuneradas, contribuições previdenciárias patronais e $13^{\circ}$ salário. 


\section{Entrevistas}

\subsection{Metodologia}

O art. 3 da Lei no 5.010, de 30/05/66, que organiza a Justiça Federal de primeira instância, determina que "[c]ada um dos Estados e Territórios, bem como o Distrito Federal, constituirá uma Seção Judiciária, tendo por sede a respectiva Capital".

Segundo a Resolução ํo 24 do Tribunal Regional Federal da $2^{\text {a }}$ Região ${ }^{33}$, de 11/10/10, aSeção Judiciária do Estado do Rio de Janeiro (SJERJ) se subdivide em várias Regiões e Subseções. O presente trabalho se limitou à Região da Capital, composta por uma única Subseção.

Todas as dez Varas Criminais da Subseção da Capital da SJERJ foram contatadas por telefone e e-mail, tendo se conseguido entrevistar todos os respectivos juízes titulares. As entrevistas ocorreram no período de 19/03/14 a 29/05/14, tendo quatrosido feitas pessoalmente, quatro por telefone e duas por e-mail ${ }^{34}$. As entrevistas consistiram na aplicação do questionário apresentado no anexo e aquelas feitas pessoalmente ou por telefone duraram de 20 a 40 minutos.

\subsection{Resultados}

Abaixo se apresentam os resultados das entrevistas seguindo a sequência dos itens do questionário. Registre-se que, apesar de o intérprete ser necessário também quando uma testemunha não fala o português, ficou claro no curso das entrevistas que o caso típico envolve réu estrangeiro. Assim, para maior praticidade, os comentários abaixo fazem mençãosomente a "réu".

Apenas dois dos juízes entrevistados afirmaram conhecer alguma norma ou recomendação relativa à atuação do intérprete em juízo adicionalmente ao que diz a legislação. Contudo, suas respostas podem ser consideradas um "sim relativo" porque um dos entrevistados se referiu ao Manual Prático de Rotinas das Varas Criminais e de Execução Penal de forma vaga e incerta ${ }^{35}$ e, como se

\footnotetext{
${ }^{33}$ A $2^{\text {a }}$ Região da Justiça Federal abarca os estados do Rio de Janeiro e do Espírito Santo.

${ }^{34}$ Duas das entrevistas pessoais foram posteriormente complementadas, uma por e-mail e outra por telefone.

35 "O CJF publicou um manual que eu acho que diz algo sobre isso".
} 
viu na Seção 2.3.2, tal documento nada acrescenta aos dispositivos legais genéricos, e o outro mencionou apenas normas de cadastramento de tradutores e intérpretes.

Quatro dos entrevistados disseram não permitir que o intérprete tenha contato prévio ao momento da audiência com o réu. Um dos juízes que respondeu negativamente, porém, observou que isso pode acontecer fortuitamente, dando a entender não haver a preocupação de impedir o encontro.

Inversamente, dois dos seis juízes que responderam positivamente disseram que o encontro pode ocorrer se o réu ou seu advogado/defensor o desejar, dando a entender não ser isso por ele (o juiz) promovido. Noutro extremo, outro dos entrevistados disse incentivar o encontro entre o réu e o intérprete.

Independentemente das respostas, cabe mencionar que réu e intérprete podem já ter tido contato em etapa anterior do processo, por exemplo, no momento da leitura da denúncia.

Seis juízes relataram que se dirigem diretamente ao réu, na $2^{2}{ }^{a}$ pessoa ${ }^{36}$, num dos casos, com a justificativa de que isso conferiria espontaneidade às respostas do réu, que se sentiria mais à vontade em manter um diálogo "direto" com o juiz, ainda que com a intervenção do intérprete.

Doisentrevistados informaram se dirigir apenas ao intérprete, referindo-se ao réu na $3^{\text {a }}$ pessoa. Doisentrevistados deram respostas "híbridas", dizendo que se dirigem diretamente ao réu caso ele fale um idioma que o próprio juiz entenda (p. ex., espanhol ou inglês), pedindo ajuda ao intérprete se necessário. Um desses juízes também informou que se o idioma do réu lhe for desconhecido, o diálogo é conduzido por meio do intérprete, com referência ao réu na $3^{\underline{a}}$ pessoa.

Dois entrevistados disseram que o intérprete traduz somente as perguntas feitas ao réu e as suas respostas. Os demais instruem o intérprete a interpretar para o réu tudo o quese diz durante a audiência. Um juiz definiu o intérprete como "a boca e o ouvido do réu", ao lado de quem ele (o intérprete) se

\footnotetext{
${ }^{36}$ Faz-se aqui a distinção entre a referência direta ao réu, na $2^{\text {a }}$ pessoa, e indireta, na $3^{\text {a }}$ pessoa, sempre por intermédio do intérprete. No primeiro caso, o juiz faz a pergunta diretamente ao réu, p. ex.: "Onde o Sr. estava quando foi abordado pela polícia?". No segundo caso, o juiz instrui o intérprete a fazer a pergunta ao réu, p. ex.: "Pergunte ao réu onde ele estava quando foi abordado pela polícia".
} 
senta, tendo liberdade para interromper o orador, se necessário ao bom andamento da interpretação. Outros três entrevistados também comentaram que o intérprete fica posicionado ao lado do réu.

Todos os entrevistados disseram que sempre conduzem a atuação do intérprete da mesma forma e todos também afirmaram que tudo o que se diz na audiência é gravado. Nas varas federais da capital, as audiências são gravadas com equipamento audiovisual que capta tudo o que ocorre na sala, sendo o DVD resultando incorporado aos autos ${ }^{37}$.

Convidados a avaliar genericamente a atuação dos intérpretes com base na escala muito boa, boa, regular, ruim e muito ruim, três dos entrevistados a consideraram muito boa; seis, boa e um, ruim. Não houve nenhuma resposta "regular" ou "muito ruim".

\section{Gráfico 3 - Avaliação geral da atuação dos intérpretes}

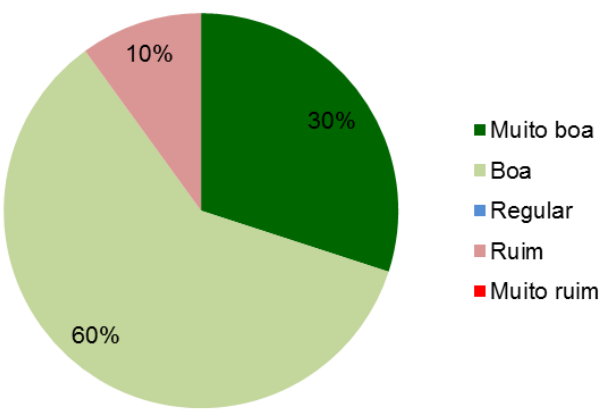

O questionamento sobre os pontos positivos e negativos da atuação dos intérpretes ensejou respostas variadas, não havendo uma lista de opções como na pergunta sobre a qualidade do trabalho.

Apenas dois entrevistados mencionaram aspectos técnicos como pontos positivos: compreensão da "liturgia" jurídica, domínio da linguagem jurídica e bom conhecimento do idioma estrangeiro. Deve-se salientar, entretanto, que um desses juízes costuma utilizar os mesmos dois advogados como intérpretes adhoc, um para inglês e francês e o outro para mandarim.

Os demais pontos positivos representavam características não técnicas: respeito ao réu, senso de humanidade e, principalmente, dedicação. Esse último item merece destaque, tendo sido mencionado por cinco juízes.

\footnotetext{
${ }^{37}$ Dá-se o nome de "auto" (ou "autos", no plural) ao conjunto de peças que compõem um processo
} 
Alguns pontos negativos listados não se referem à atuação do intérprete propriamente dita: baixa remuneração, dificuldade de encontrar intérpretes e,em um caso, a recusa dos intérpretes em visitar presídios (para cumprir etapas do processo que não as audiências, p. ex., a leitura da denúncia).

Somente dois entrevistados mencionaram pontos negativos de caráter técnico: pouco conhecimento jurídico e falta de vocabulário adequado no idioma estrangeiro. Entretanto,sete entrevistados recomendaram aos intérpretes que adquiram melhor conhecimento do processo e do vocabulário judicial. Um entrevistado propôs que os intérpretes fossem "contratados para atuar nos juízos", sem esclarecer se como funcionários públicos ou não, e que sua remuneração seja "compatível com a importância das funções".

Apenasum dos entrevistados não enumerou qualquer ponto positivo ou negativo e somente um outro se absteve de fazer recomendações para a melhoria da qualidade da interpretação.

Cinco entrevistados consideram necessário a normatização da atuação dos intérpretes e os outros cinco, não. Um dos juízes respondeu ser a normatização necessária para "evitar que o réu seja prejudicado por não saber o que as testemunhas brasileiras dizem". Outra resposta positiva enveredou pelo caminho da criação de um "corpo de intérpretes (não necessariamente servidores públicos)" e uma terceira fez referência tanto à condução da interpretação pelo juiz quanto à preparação do intérprete.

Duas respostas negativasexpressaram o temor de que a normatização tire a liberdade do juiz, engessando o procedimento. É interessante notar que um dos entrevistados contrários à normatização observou que ela poderia ter "consequências processuais importantes, abrindo as portas à arguição da nulidade do processo".

Oito entrevistados informaram necessitar de intérpretes poucas vezes por ano (duas a seis), um disse ter necessidade semanal e o último não soube precisar. Dois entrevistados esclareceram que a necessidade de intérpretes depende do foco de atuação da Polícia Federal e um terceiro creditou a recente queda no volume de réus não falantes do português (de seis para três por ano)ao desvio das rotas do tráfico internacional de drogas do Rio de Janeiro e de São Paulo para certas capitais do Nordeste. 
Nove entrevistados relataram ter utilizado intérpretes ad-hoc dada a inexistência de TPIC para o idioma em questão ou a indisponibilidade dos TPIC existentes. O décimo não respondeu diretamente a pergunta, dizendo apenas que um intérprete não cadastrado na Justiça Federal seria procurado nos consulados ou na JUCERJA ${ }^{38}$.Um entrevistado disse que a necessidade de intérpretes ad-hoc é "muito grande" e outro categorizou como "desgastante" a busca por intérpretes.

Quatro entrevistados disseram serem os consulados a principal fonte de intérpretes ad-hoc e dois sugeriram que se criasse um "banco" de intérpretes.

${ }^{38}$ Havendo evidente contrassenso: um intérprete registrado na JUCERJA é, por definição, um TPIC, não sendo, igualmente por definição, ad-hoc. 


\section{Conclusões}

Não obstante o pequeno número absoluto de entrevistados (dez), essa amostra é significativa porque representa a totalidade das varas criminais da Seção Judiciária do Rio de Janeiro.

A análise da legislação e das entrevistas demonstra que:

- afora a determinação genérica do recurso à interpretação quando um réu ou testemunha não fala o português, a legislação não explicita como o juiz deve conduzir a atuação do intérprete. Cada juiz age como the parece mais adequado;

- uma pequena maioria dos juízes permite que o intérprete e o réu, seu advogado ou defensor confabulem antes da audiência;

- a grande maioria dos juízes se dirige diretamente ao réu e instrui o intérprete a interpretar tudo o que se diz na audiência e não apenas as perguntas feitas ao réu e as suas respostas;

- a avaliação da atuação dos intérpretes é majoritariamente positiva, mas eles carecem de conhecimento técnico-jurídico;

- a dedicação é tida como a maior qualidade dos intérpretes e a baixa remuneração - que os fatos corroboram - é um problema grave, o intérprete é visto como um auxiliar da Justiça movido primordialmente pelo desejo de ajudar e não como um profissional que cumpre o seu papel;

- o problema da remuneração e a necessidade de interpretação para idiomas para os quais não há TPIC no Estado do Rio de Janeiro (principalmente idiomas africanos ou chineses) torna imprescindível o recurso aos intérpretes ad-hoc;

- uma pequena maioria dos juízes crê ser desnecessária a normatização da atuação do intérprete em audiências.

As conclusões acima confirmam minha "hipótese oculta", mera intuição, de que, nos limites da lei, cada juiz conduz a atuação do intérprete de tribunal como acha que deve, o que tem implicações importantes. Não será prejudicado o réu não falante do português que não entender o que dizem os outros participantes da audiência ou que não tenha a oportunidade de se comunicar de forma direta e mutuamente inteligível com seu advogado/defensor? 
Nesse sentido, seria talvez recomendável que a liberdade do juiz fosse limitada com a criação de normas que, sem minúcia exagerada, estabeleçam certos procedimentos básicos a serem seguidos em benefício do réu não falante do português e, em última instância, da própria Justiça.

Não obstante a satisfação dos juízes com os intérpretes, é preocupante o fato de que a sua grande qualidade e seu maior defeito, na opinião dos juízes, sejam respectivamente a grande dedicação e o pouco conhecimento técnicojurídico. As entrevistas deixaram a impressão de que os juízes sabem que estão recorrendo a pessoas mal preparadas ${ }^{39}$ e mal pagas, aceitando isso como "um fato da vida". Não seria melhor, de novo em benefício do réu e da Justiça, a Justiça Federal oferecer remuneração no mínimo razoável de modo a atrair profissionais gabaritados?

Essas são questões que merecem a atenção não apenas das entidades de classe (SINTRA, ATP-Rio), mas também daquelas voltadas à própria Justiça (CJF, TRFs, OAB).

O presente trabalho indica várias possibilidades de desdobramento. Em "nível horizontal", o desdobramento seria quantitativo, em um ou mais de três eixos:

- eixo geográfico: inclusãona pesquisa das demais varas criminais da SJERJ;

- eixo da competência:inclusão de varas de outras competências ainda dentro da Justiça Federal, por exemplo, as cíveis, ou de varas de diversas competências (criminais, cíveis, de família) dentro da Justiça Estadual;

- eixo da instância: inclusão da $2^{\underline{a}}$ instância (sessões do TRF-2).

Em "nível vertical", o desdobramento seria qualitativo com grande gama de possibilidades, por exemplo:

- estudos de caso: consultar os autos de determinados processos para analisar os efeitos dos aspectos aqui mencionados (uso de intérpretes não profissionais, forma de condução da sua atuação pelo juiz etc.);

\footnotetext{
${ }^{39}$ Mesmo um advogado, que por definição conhece o sistema e o linguajar jurídico brasileiro, e que seja fluente no idioma estrangeiro em questão não será necessariamente um bom intérprete.
} 
- análises de perfil: entrevistas com intérpretes ad-hoc com o objetivo de analisar o seu grau de competência e de preparação técnica;

- análises estatísticas: estatística faz pensar em quantidade, mas incluo essa análise aqui porque seu objetivo seria calcular certos indicadores que aprofundem a discussão dos temas aqui tratados no mesmo universo da pesquisa original (varas criminais da Subseção da Capital SJERJ), por exemplo: com que frequência TPICs e intérpretes ad-hoc são utilizados? Quais idiomas dependem mais de uns e de outros?

E nada impede, é claro, que um ou mais desses níveis, eixos e opções sejam combinados, abrindo um leque virtualmente infinito de possibilidades de pesquisa.

Finalmente, cabe acrescentar que este é um trabalho pioneiro, que abre caminho para o estudo e a compreensão do nicho da interpretação de tribunal, contribuindo não apenas para os estudos de interpretação, mas também para o Direito. 


\section{Referências bibliográficas}

ADMINISTRATIVE OFFICE OF THE UNITED STATES COURTS, Court Services Office.Federal Court Interpreter Orientation Manual and Glossary.[S.I.], 2014.Disponívelem

<http://www.uscourts.gov/FederalCourts/UnderstandingtheFederalCourts/District Courts/CourtInterpreters/InterpreterSkills.aspx>. Acesso em 22/04/14.

ATKINSON, Rebecca Frances. O intérprete em seu meio profissional: Por uma voz mais alta. Dissertação de Mestrado. Programa de Pósgraduação em Letras. PUC-Rio, Rio de Janeiro, 2006. Disponível em $<$ http://www.dominiopublico.gov.br/pesquisa/DetalheObraForm.do?select_action $=\&$ co_obra=30427 $>$. Acesso em 03/12/13.

BRASIL. Decreto 2.848, de 07/12/40 [Código Penal].Disponível em <http://www.planalto.gov.br/ccivil_03/decreto-lei/Del2848compilado.htm>. Acesso em 23/04/14.

BRASIL. Decreto 8.001, de 10/05/13, Disponível em <http://www.planalto.gov.br/ccivil_03/_Ato2011-2014/2013/Decreto/D8001.htm>. Acesso em 10/05/14.

BRASIL. Decreto 13.609, de 21/10/43.Disponível em <http://www.planalto.gov.br/ccivil_03/decreto/1930-1949/D13609.htm>. Acesso em 21/04/14.

BRASIL. Decreto de 05/09/91. Disponível em <http://www.planalto.gov.br/ccivil_03/DNN/Anterior\%20a\%202000/Dnn7-05-0991.htm\#art3>. Acesso em 21/04/14.

BRASIL. Decreto de 22/06/93. Disponível em <http://www.planalto.gov.br/ccivil_03/dnn/Anterior\%20a\%202000/Dnn1-22-0693.htm>. Acesso em 21/04/14.

BRASIL. Decreto-Lei 3.689, de 03/10/41 [Código de Processo Penal]. Disponível em <http://www.planalto.gov.br/ccivil_03/decretolei/Del3689Compilado.htm>. Acesso em 23/04/14.

BRASIL. Decreto-Lei 5.452, de 01/05/43 [Consolidação das Leis do Trabalho]. Disponível em <http://www.planalto.gov.br/ccivil_03/decretolei/Del5452compilado.htm>. Acesso em 23/04/14.

BRASIL. Lei 5.010, de 30/05/66. Disponível em <http://www.planalto.gov.br/ccivil_03/leis/L5010compilado.htm>. Acesso em 29/05/14.

BRASIL. Lei 5.869, de 11/01/73 [Código de Processo Civil]. Disponível em $<$ http://www.planalto.gov.br/ccivil_03/leis/L5869compilada.htm>. Acesso em 23/04/14.

BRASIL. Lei 8.934, de 18/11/94. Disponível em <http://www.planalto.gov.br/ccivil_03/leis//8934.htm>. Acesso em 19/04/14.

BRASIL. Lei 9.307, de 23/09/96 [Lei de Arbitragem]. Disponível em <http://www.planalto.gov.br/ccivil_03/leis/19307.htm>. Acesso em 19/04/14. 
BRASIL. Lei 10.406, de 10/01/02 [Código Civil]. Disponível em <http://www.planalto.gov.br/ccivil_03/leis/2002/L10406compilada.htm>. Acesso em 23/04/14.

BRASIL. Lei 11.416, de 15/12/06. Disponível em <http://www.planalto.gov.br/ccivil_03/_ato2004-006/2006/lei/l11416.htm>. Acesso em 20/04/14.

BRASIL. Projeto de Lei 6889/2013. Disponível em <http://www.camara.gov.br/proposicoesWeb/fichadetramitacao?idProposicao $=60$ 3315>. Acesso em 01/05/14.

BRASIL. Conselho da Justiça Federal. Resolução no 558, de 22/05/07. Disponível em <http://www2.cjf.jus.br/jspui/handle/1234/2>. Acesso em 20/04/14.

BRASIL. Conselho Nacional de Justiça.Manual Prático de Rotinas das Varas Criminais e de Execução Penal. Brasília: 2009. Disponível em<http://www.cnj.jus.br/images/programas/justica-criminal/manual-rotina-varascriminais-cnj.pdf>. Acesso em 31/03/14.

BRASIL. Conselho Nacional de Justiça.Plano de Gestão parao Funcionamento deVaras Criminais e deExecução Penal. Brasília: 2009. Disponível em<http://www.cnj.jus.br/images/programas/justica-criminal/planogestao-varas-criminais-cnj.pdf>. Acesso em 31/03/14.

BRASIL. Departamento de Registro Empresarial e Integração.Instrução Normativa 17, de 05/12/13, Disponível em $<$ http://drei.smpe.gov.br/legislacao/instrucoes-normativas/titulo-menu/pastainstrucoes-normativas-em-vigor-02-1/drei-17.pdf>. Acesso em 10/05/14.

BRASIL. Departamento Nacional do Registro do Comércio. Instrução Normativa 84, de 29/02/2000. Disponível em <http://www.dnrc.gov.br/Legislacao/normativa/in84.htm>. Acesso em 01/05/14.

BRASIL. Tribunal Regional Federal da 2a Região.Resolução 24, de 11/10/10. Disponível em <http://www.jfrj.jus.br/documentos/grupo_68/ResPres201000024_TRF2.pdf>. Acesso em 29/05/14.

DE JONGH, Elena M. Court Interpreting: Linguistic Presence v. Linguistic Absence. The Florida Bar Journal, July/August, 2008 Volume 82, No. 7. Disponível em <http://www.floridabar.org/DIVCOM/JN/JNJournal01.nsf/Author/ 089C9FC08403FDF885257471005ECF98>. Acesso em 17/04/14.

EDWARDS, Alicia Betsy. The Practice of the Court Interpreter.Amsterdam: John Benjamins, 1995.

GINEZI, Luciana Latarini. A ética na interpretação de tribunal: o Brasil no banco dos réus. TradTerm, São Paulo, v. 20, dezembro/2012, p. 27-42. Disponível em <http://www.revistas.usp.br/tradterm/article/view/49040/53111>. Acesso em 03/12/13.

HALE, Sandra Beatriz. The Discourse of Court Interpreting.Amsterdam: John Benjamins, 2004. 
HATIM, B.; MASON, I. Discourse and the Translator. London: Longman, 1990.

HERBERT, Jean. The Interpreter's handbook.Genève: Librarie de L'Université, 1952.

INSTITUTO ANTÔNIO HOUAISS. Dicionário Houaiss da Língua Portuguesa. Rio de Janeiro: Objetiva, 2001.

JONES, Roderick. Conference Interpreting Explained. Manchester: St. Jerome, 2002.

MIKKELSON, Holly. Verbatim Interpretation: An Oxymoron. [Sem local e sem data]. Disponível em <http://www.acebo.com/papers/verbatim.htm>. Acesso em 19/04/14.

MIKKELSON, Holly. Interpreting Is Interpreting - Or Is It?In: GSTI 30th Anniversary Conference, 1999, [S.I]. Disponível em <http://www.acebo.com/papers/INTERP1.HTM>. Acesso em 19/04/14.

MIKKELSON, Holly. Court Interpreting at a Crossroads. In: Annual Conference of the National Association of Judiciary Interpreters and Translators, 1999,[S I.]. Disponível em <http://www.acebo.com/papers/crossr 1.htm>. Acesso em 17/04/14.

MIKKELSON, Holly.Consecutive or Simultaneous?An Analysis of Their Use in the Judicial Setting.Across the Board, Australian Sign Language Interpreters Association Vol. 5 No. 1, 2010, pp. 4-7. Disponível em <http://www.acebo.com/papers/conorsim.htm>. Acesso em 19/04/14.

MINISTÉRIO DO TRABALHO E EMPREGO - MTE. Classificação Brasileira de Ocupações. Brasília: 2010, Livro 1. Disponível em <http://www.mtecbo.gov.br/cbosite/pages/downloads.jsf>. Acessoem 18/04/14.

MORRIS, Ruth. Images of the court interpreter: Professional identity, role definition and self-image. Translation \& Interpreting Studies, [S I.], 2010, vol. 5 issue $\quad 1$, p. 20.Disponívelem<http://www.ruth-morris.info/wpcontent/uploads/2010/03/ImagesTIS2010.pdf>.Acessoem 19/04/14.

NATIONAL ASSOCIATION OF JUDICIARY INTERPRETERS AND TRANSLATORS.Code of Ethics and Professional Responsibilities.Washington, D.C., [sem data]. Disponível em <http://www.najit.org/about/NAJITCodeofEthicsFINAL.pdf>. Acessoem 22/04/14.

NATIONAL ASSOCIATION OF JUDICIARY INTERPRETERS AND TRANSLATORS.Terms of the Profession.Washington, D.C., [sem data]. Disponível em:

<http://www.najit.org/certification/Terms\%20of\%20the\%20Profession.pdf>.

Acessoem 22/04/14.

NATIONAL ASSOCIATION OF JUDICIARY INTERPRETERS AND TRANSLATORS.Modes of Interpreting: Simultaneous, Consecutive, \& Sight Translation. Washington, D.C., 2006. Disponível em: $<$ http://www.najit.org/publications/Modes_of_Interpreting200609.pdf>. Acesso em 22/04/14. 
NEJM,Carla Cynira Lima.Interpretação Simultânea: a Linguística de Corpus na Preparação dos Intérprete. Dissertação de Mestrado. Programa de PósGraduação emEstudos Linguísticos e Literários do Inglês,USP, São Paulo, 2011. Disponível em <http://www.teses.usp.br/teses/disponiveis/8/8147/tde-29092011095400/pt-br.php>. Acesso em 26/04/14.

NOVAIS NÉTO, Lourival. 0 intérprete de tribunais no Brasil: peritusperitorum? Tese de doutorado. Programa de Linguística Aplicada e Estudos da Linguagem. PUC-SP, São Paulo, 2009. Disponível em <http://www.dominiopublico.gov.br/pesquisa/DetalheObraForm.do?select_action $=\&$ co_obra $=145601>$. Acesso em 03/12/13.

PAGURA, Reynaldo José. A Interpretação de conferências no Brasil: história de sua prática profissional e a formação de intérpretes brasileiros. Tese de doutorado. Programa de Pós-Graduação emEstudos Linguísticos e Literários do Inglês,USP, São Paulo, 2010. Disponível em $<$ http://www.teses.usp.br/teses/disponiveis/8/8147/tde-09022011-151705/ptbr.php>. Acesso em 26/04/14.

PASSOS, Deusa Maria de Souza Pinheiro. O intérprete como produtor de sentidos: uma análise discursiva da atividade de interpretação forense. TradTerm, São Paulo, v. 15, 2009, p. 113-131. Disponível em <http://www.revistas.usp.br/tradterm/article/view/46342>. Acessoem 30/03/14.

PHELAN, Mary. The Interpreter's Resource.Clevedon: Multilingual Matters, 2001.

REIS, Evelin Rebeca Gazeta dos. Algumas considerações sobre a interpretação forense no Brasil. Trabalho de Conclusão de Curso do Centro Universitário Adventista de São Paulo dos cursos de Letras e Tradutor e Intérprete. Engenheiro Coelho, 2013. Disponível emhttp://getiunasp.files.wordpress.com/2013/12/algumas-considerac3a7c3b5essobre-a-interpretac3a7c3a3o-forense-no-brasil.pdf. Acesso em 30/03/14.

RIO DE JANEIRO (Estado). Junta Comercial do Estado do Rio de Janeiro. Edital no 01/2009. Rio de Janeiro, 2009. Disponível em <http://www.jucerja.rj.gov.br/concurso/pdf/JUCERJA\%20TRADUTOR\%20E\%20I NTERPRETE\%20VERS.pdf>. Acesso em 19/04/14.

RIO DE JANEIRO (Estado). Junta Comercial do Estado do Rio de Janeiro. Edital. Rio de Janeiro, 2010. Disponível em $<$ http://200.198.188.123/download/provas/jucerja09_resultadofinal_diariooficial.p df>. Acesso em 23/04/14.

RIO DE JANEIRO (Estado). Junta Comercial do Estado do Rio de Janeiro. Deliberação no 55/2012, de 09/04/12. Rio de Janeiro, 2012. Disponível em $<$ http://www.jucerja.rj.gov.br/legislacao/deliberacao/Deliberacao_55.pdf >. Acesso em 20/04/14.

SANTOS, Washington. Dicionário Jurídico Brasileiro. Belo Horizonte: Del Rey, 2001.

TAYLOR-BOULADON, Valerie. Conference interpreting, principles and practice.[S. I.]: BooksurgePublishing, 2011. 


\section{Anexo - Roteiro de Entrevista}

Data:

Hora:

Local:

Entrevistado:

Vara:

1) $O \operatorname{Sr}(a)$. tem conhecimento de alguma norma/recomendação relativa à atuação do intérprete em juízo? Quais?

2) Independentemente das eventuais normas/recomendações existentes, como o Sr(a). conduz a atuação do intérprete?

2.a) O intérprete tem contato prévio com o réu, com a defesa e/ou com a acusação?

Na audiência:

2.b) As perguntas são feitas diretamente ao réu ou ao intérprete?

2.c) O intérprete traduz apenas as perguntas feitas ao réu e suas declarações ou também as perguntas feitas aos demais participantes da audiência e as respectivas declarações?

2.d) Somente a tradução do intérprete é gravada ou também o são as declarações do réu no idioma original?

3) Essa atuação é sempre conduzida da mesma forma? Em caso negativo, por quê?

4) Como o(a) Sr(a). avalia, de forma geral, a atuação dos intérpretes com quem trabalhou:

$\square$ Muito boa $\quad \square$ Boa $\quad \square$ Razoável $\quad \square$ Ruim $\quad \square$ Muito ruim

5) Quais aspectos positivos e/ou negativos o(a) $\operatorname{Sr}(a)$. teria a destacar no trabalho desses profissionais?

6) Como os intérpretes poderiam aprimorar o serviço que prestam?

7) $\mathrm{O} \operatorname{Sr}(\mathrm{a})$. teria alguma recomendação ou preferência a manifestar relativamente à interpretação em juízo? A normatização é necessária?

8) Quantas vezes o $\operatorname{Sr}(a)$. necessitou do auxílio de um intérprete no último ano (ou em qualquer outro período)? 
9) O Sr(a). já necessitou convocar um intérprete "ad hoc" dada a falta/indisponibilidade de intérpretes juramentados para o idioma em questão (qual)? Como o intérprete foi encontrado?

10) Observações 